Krystyna NAJDER-STEFANIAK

KNH SGGW Warszawa

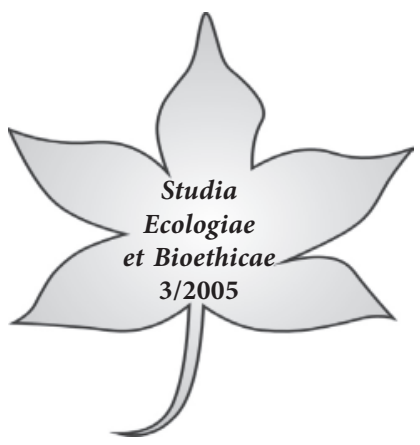

\title{
Kultura ekologiczna zamiast kultury doraźności
}

Wiek XX, który dostarczył wydarzeń nazywanych „katastrofą, jaka przetoczyła się przez cywilizację europejską i słowiańską"1 i przyczynił się do kariery pojęcia „cywilizacja śmierci”, wymaga sformułowanej z perspektywy etyki odpowiedzi człowieka na świat, jaki w wyniku jego aktywności został zaktualizowany. Odpowiedzi mogą być dwojakiego rodzaju. Mogą polegać albo na dostosowaniu się do sytuacji albo na twórczym jej przekroczeniu. Przykładem pierwszego typu odpowiedzi na doświadczenia, jakich dostarczył człowiekowi wiek XX jest kultura doraźności. Przykładem odpowiedzi twórczej jest kultura ekologiczna.

Kultura doraźności, jest odpowiedzią wpisującą się w ten sam paradygmat myślenia, który skutkował wydarzeniami sprawiającymi że trudno dziś kontynuować oświeceniową wiarę w to, że oświata, powszechne kształcenie, rozwój wiedzy i możliwości technicznych będą sprzyjać powstawaniu dostatniego świata i przyjaznych relacji między ludźmi. Wiemy już, że „wyrafinowany intelektualizm, artystyczna wirtuozeria i kunszt, znakomitość naukowa mogą aktywnie służyć żądaniom totalitaryzmu, czy chociażby spoglądać obojętnie na szerzący się wokół sadyzm"2, że w racjonalnie zaplanowanych obozach śmierci może rozbrzmiewać wspaniała muzyka wielkich kompozytorów. W dodatku człowiek wymyślający zadziwiające rozwiązania techniczne i odkrywający prawdy pozwalające na ingerencję w skomplikowane procesy natury nie potrafi zatrzymać niszczenia własnego społeczno-przyrodniczego środowiska i degradacji samego siebie. Źródłem tej bolesnej klęski oświeceniowych nadziei musi być jakiś fałsz w podstawowych założeniach i schematach myślenia. Fałsz, który doprowadził do aktualizowania przestrzeni nieprzyjaznych człowiekowi, przestrzeni zmuszających człowieka by przestał przeżywać swoje istnienie jako trwanie zespalające doświadczenie wewnętrzne i zewnętrzne. By uczynił je zbiorem punktowych zdarzeń-przeżyć nagle dosięgających człowieka w postaci szoku, punktowych przeżyć, które przyjmujemy do wiadomości jako momenty nie mające wymiaru ani w czasie, ani w przestrzeni. Wypierają one doświadczenie, które tym się

1 G. SteIner, Gramatyki tworzenia, tłum. Jerzy Łoziński, Wydawnictwo Zysk i S-ka, Poznań 2004.

2 Jw. s. 10. 
różni od szokowego przeżycia, że ma związek z tradycją, wyróżnia się ciągłością i wzbogaca osobowość człowieka ${ }^{3}$.

Kultura doraźności ma korzenie w paradygmacie redukcjonistycznego, analitycznego, antagonizującego myślenia nowożytnego, podobnie jak świat, będący efektem wynikających z tego myślenia działań, który dostarczając nadmiaru wrażeń i bardzo skrótowych informacji implikuje doznawanie rzeczywistości, potwierdzające sens tej kultury. Z nowożytnego paradygmatu myślenia wyrastają dwa pojęcia czasu pozbawionego wymiaru przyszłości: Kartezjańskie i Bergsonowskie, które choć różne, współbrzmią z kulturą doraźności. Wymiaru przyszłości pozbawiona jest zarówno teraźniejszość w bycie punktowym jak i pochłaniająca przeszłość, rozrastająca się wciąż teraźniejszość Bergsona.

Pojęcie czasu inspirowało do rozważań filozoficznych już myślicieli starożytnych. Z platońskiego Timajosa dowiadujemy się, że „byt”, „przestrzeń” i „powstanie" istniały zanim powstał świat. Ten ostatni, Demiurg wykonał według doskonałego wzoru, który zawsze jest taki sam a więc jest ponadczasowy, czy bezczasowy, wieczny. Świat-wszechświat będący żywym organizmem, a więc posiadający duszę został stworzony jako jeden i doskonały, co skutkuje tym, że nie może się zmieniać. Ma początek i wieczną teraźniejszość. Czas istnieje jednak wewnątrz tego świata i dotyczy stawania się bytów będących „cieniami” idei. Arystoteles, rozpatrywał czas jako miarę ruchu i ukierunkowywał myślenie ujmujące czas jako atrybut lub aspekt ruchu ${ }^{4}$. Dla arystotelików ruch pełni funkcję różnicowania materialnego, bezkształtnego podłoża a czas to miara ruchu. W Fizyce czytamy, że czas „jest ilościową stroną ruchu”, że jest „rodzajem ilości”. Ruch-zmiana sprawia, że pojawia się jakieś „przed” i „po”, zauważa Arystoteles i dodaje: „także w czasie występuje «przed» $i$ «po», bo czas i ruch zawsze sobie wzajemnie odpowiadają." Zdaniem Arystotelesa ruch jest ciągły i proporcjonalny do ruchu czas także. Czas składa się nie tylko z „przed” $\mathrm{i}$ „po", ale też z tego, co po środku, z „teraz”.

Na gruncie myśli teologicznej średniowiecza zrodziła się refleksja nad czasem ujmowanym jako trwanie. Dla zrozumienia rozpatrywanych w ramach tej refleksji zagadnień potrzebne okazały się specyficzne pojęcia dotyczące czasowości. Jedno z nich to aeternitas - pojęcie graniczne równe bezczasowości i przynależne tylko Bogu. Inne to aevum - pojęcie czasowości przysługujące bytom duchowym, oznaczające czas, który ma początek, ale nie ma końca. W refleksji nad trwaniem czas przestaje być uniwersalną, obiektywną miarą ruchu-zmiany staje się subiektywnym przeżywaniem trwania. Subiektywne rozumienie czasu, siedliskiem którego jest ludzki duch zainspirowało Aureliusza Augustyna do zajęcia się

3 K. Sauerland, Od Diltheya do Adorna. Studia z estetyki niemieckiej, PIW, Warszawa 1986 s. 151.

4 Physike IV 11. 218b-219a-219b, tłum. B. Kupis [w:] Jan Legowicz, Teksty wybrane z historii filozofi. Filozofia Starożytna, PWN, Warszawa 1968, s. 212. 
problematyką świadomości czasu i zagadnieniem teraźniejszości oraz przeszłości i przyszłości.

Augustyn rozpoczyna swoje słynne rozważania o czasie od paradoksu polegającego na tym, że jednocześnie wiemy i nie wiemy czym jest czas. Wiemy, bo go doświadczamy, nie wiemy, gdy próbujemy zrozumieć. Zdaniem Augustyna odpowiedzi na pytanie: Czym jest czas? powinniśmy szukać poprzez doświadczenie subiektywnego i modalnego czasu wewnętrznego. Ten czas można sprowadzić do trzech modi obecności: 1/ pamięci, czyli istniejącej w duszy obecności przeszłości, 2/ aktualnego spostrzegania, czyli obecności teraźniejszości i 3/ oczekiwania, czyli obecności przyszłości. ${ }^{5} \mathrm{~W}$ koncepcji Augustyna teraźniejszość nie redukuje się do nieuchwytnego momentu między przeszłością, której już nie ma a przyszłością, której jeszcze nie ma, trwa zawierając w sobie pamięć przeszłości i oczekiwanie przyszłości.

Akcent na trwanie czasu stawia też Bergson, w koncepcji którego przeszłość nie mija, lecz pozostaje składając się razem z teraźniejszością na wciąż twórczo kontynuujące się trwanie. Metaforą takiego czasu jest tocząca się śnieżna kula. Bergsonowski czas nie potrafi jednak przekroczyć rozrastającej się wciąż teraźniejszości. Jest ona efektem twórczości, która polega na tym, że nasze działanie „wypływa ze swych poprzedników na mocy ewolucji sui generis w ten sposób, że odnajdujemy w nim poprzedniki, które je tłumaczą, a (...) dodaje do nich coś zupełnie nowego stanowiącego postęp, podobnie jak owoc stanowi postęp w stosunku do kwiatu"6. Bergsonowski czas składa się z przeszłości dostępnej dzięki pamięci i teraźniejszości, czyli aktualnego bycia. Nie ma w nim obecności przyszłości, którą zastępuje nieustannie nowa teraźniejszość. Czas bez przyszłości, to rozumienie czasu, z którego łatwo wyrasta kultura doraźności.

U Platona czas jest związany z porządkiem zachodzenia zmian. Dla Arystotelesa czas jest atrybutem ruchu i miarą jego ilości. Dla Augustyna i Bergsona czas jest atrybutem trwania i miarą bycia bytu. Wszystkie te czasy są realne. Zmienia się w istotny sposób rozumienie czasu u Kartezjusza. Czas przestaje tu być „ilością ruchu” staje się „liczbą ruchu”. W Zasadach filozofii czytamy: „.... skoro odróżniamy czas od ogólnie branego trwania i skoro mówimy, że jest on liczbą ruchu, to jest on tylko modyfikacją myślenia. Bo doprawdy nie pojmujemy w ruchu innego trwania aniżeli w rzeczach, które się poruszają, skąd jasno widać, że jeśli dwa ciała, jedno powoli, drugie szybciej poruszają się w ciągu godziny, nie wyliczymy więcej czasu w jednym niż w drugim, choć o wiele więcej jest w nim ruchu."7

\footnotetext{
Augustyn: Wyznania, tłum. Z. Kubiak, Wydawnictwo. Platan, Kraków 1994, księga XI, rozdział 14 .

6 H. Bergson, Materia i pamięć, tłum. K. Bobrowska, Warszawa 1930, s. 170.

7 Descartes, Zasady filozofii, tłum. I. Dąbska, PWN, Warszawa 1960, s. 35.
} 
Kartezjusz otwiera na możliwość abstrakcyjnego rozumienia czasu. Pisze: „Trwanie, porządek, liczbę rozumiemy też najwyraźniej, jeżeli tylko nie będziemy dokomponowywać do nich jakiegoś pojęcia substancji, a tylko sądzić będziemy, że trwanie jakiejkolwiek bądź rzeczy jest wyłącznie modyfikacją, poprzez którą pojmujemy samą tę rzecz, o ile ona utrzymuje się w istnieniu."8 Ponadto Kartezjański czas traci ciągłość: „...jeśli uprzytomnimy sobie istotę czasu, czyli trwania rzeczy; jest ona taka, że części czasu wzajemnie od siebie nie zależą ani nigdy nie współistnieją. Toteż z tego, że już jesteśmy, nie wynika, że będziemy w najbliżej następującym czasie, o ile jakaś przyczyna, ta mianowicie, która nas wpierw stworzyła, nie będzie nas jak gdyby wciąż na nowo stwarzała, tj. zachowywała"'.

Kartezjusz proponuje wyobrażenie i pojęcie czasu uniwersalnego: „Lecz by zmierzyć trwanie wszystkich rzeczy, porównujemy je z trwaniem tych największych i najrówniejszych ruchów, przez które powstają lata i dnie i to właśnie trwanie nazywamy czasem. Co zatem nie dodaje trwaniu wziętemu ogólnie nic, prócz modyfikacji myślenia." ${ }^{10}$ Czas uniwersalny, nieskończenie podzielny, równomiernie płynący, to wyobrażenie związane $\mathrm{z}$ wizją niezmiennej wieczności. Taki czas jest niezbędny nauce, bo umożliwia dokładną powtarzalność i w efekcie koincydencję operacji badawczych przeprowadzonych w innym miejscu przestrzeni i czasu. Taki uniwersalny czas, jako punkt odniesienia, wprowadza porządek chroniący konstrukty rozumu przed pogrążeniem się $\mathrm{w}$ chaosie ${ }^{11}$. Z kulturą doraźności współbrzmi abstrakcyjność i nieciągłość kartezjańskiego czasu. Kartezjańska teraźniejszość jest punktowa, nie ma ani przeszłości ani przyszłości.

Wymiar przyszłości, to wymiar transcendencji. Implikuje on pojęcie nadziei i pojęcie trwogi, a jeśli do rozważań wprowadzimy pojęcie wolności - także pojęcie odpowiedzialności. Dowodem nadziei jest modlitwa zawierzająca przyszłość Bogu, ale też metafizyka wyrastająca z przekonania o racjonalnej podstawie świata. W kulturze doraźności obie i modlitwa i filozofia stają się zbyteczne. Ludzie tracą kontakt z sacrum i z metapoziomem rozumienia. Obce im są doświadcze-

11 U Newtona staje się bytem samoistnym, jednorodnym, ciągłym, jednowymiarowym i biegnie, czy może lepiej upływa równomiernie. Możemy zobrazować go za pomocą prostej zakończonej strzałką. Jako anizotropowy, czas płynie od przeszłości do przyszłości. Równolegle w fizyce funkcjonuje zasada izotropowości, która głosi, że prawa fizyki są symetryczne w czasie, że wszystkie procesy fizyczne są odwracalne /prosta bez strzałki/ oraz teoria struktur rozgałęzionych, która rezygnuje $\mathrm{z}$ ambicji opracowania teorii wyjaśniającej anizotropowość czasu i podejmuje zadanie skromniejsze: wyjaśnienia faktycznego porządku czasowego zdarzeń w dostępnym człowiekowi obszarze wszechświata.
} 
nia mistyczne, bo te wymagają przekroczenia granic zaktualizowanego bycia, czyli granic teraźniejszości. Doświadczenia estetyczne zaś stają się specyficzne, pozwalają uwolnić się pamięci ze schematów narzucanych jej przez aktualne spostrzeganie, ale nie wprowadzają $\mathrm{w}$ otwartość piękna pomagającego dotknąć sacrum. W dziełach artystów zamkniętych w doraźności znajdujemy jedynie tęsknotę za sacrum lub pustkę po nim. Znikają związane $\mathrm{z}$ wymiarem transcendencji: nadzieja i trwoga. Pozostaje płytki, nieprzyjemny, niepokojący lęk. George Steiner zwraca uwagę na to, że nadzieja i trwoga swą moc zawdzięczają syntaksie: „Nadzieja kryje w sobie trwogę niespełnienia, trwoga zawiera gorczyczne ziarno nadziei, delikatną sugestię zwycięstwa" ${ }^{12}$. Człowiekowi, który koncentruje się na tym, co doraźne obca jest zarówno nadzieja jak i trwoga. W rezultacie nie jest on w stanie doznawać ich współkonstytuowania się. Pozbawiony nadziei lęk, nie dodaje mocy. Choć płytki, jeśli nie potrafimy go poddać racjonalizacji, paraliżuje i karze uciekać w bezmyślność i brak poczucia odpowiedzialności. Bez poczucia odpowiedzialności niedostępny staje się wymiar etyki, wymiar tego, co być powinno. Niedostępne i niezrozumiałe stają się też twórcze myślenie i twórcze działanie. Człowiek, który dostał się w pułapkę doraźności nie tworzy, bo twórczość jest wychodzeniem poza aktualność a doraźność zamyka się w tym, co zaktualizowane.

Czy z pułapki doraźności wyzwolić może metanoia? W starożytnej Grecji metanoia oznaczała przemianę duchową, w przeciwieństwie do metamorfozy dotyczącej zmiany postaci. W Biblii jest metanoia przemianą wewnętrzną, której negatywnym aspektem była skrucha za coś, co się kiedyś czyniło i z czym nie chcemy się już identyfikować, zaś pozytywnym - zwrócenie się do Boga. W Nowym Testamencie znajdujemy dwa słowa: metanoia i metamelomai. Pierwsze oznacza zmianę umysłu i odnosi się przede wszystkim do sfery intelektualnej, choć nie wyklucza elementów emocjonalnych. Drugie oznacza stan, w którym żałujemy za niewłaściwe postępowanie. Negatywny stan żalu jest łatwiejszy do osiągnięcia niż konstruktywna metanoia. Jednak „metamelomai” bez możliwości zmiany musi skutkować depresją albo kulturą doraźności, która choć odrzuca oświeceniowe założenia i cele, wpisuje się bardzo dobrze w nowożytny redukcjonistyczny $i$ analityczny paradygmat myślenia.

Metanoia jest aktywnością podmiotową. Podstawą każdej metanoi jest jednak jednocześnie jakieś zawierzenie komuś lub czemuś, kto lub co przekonuje nas do tego, że możemy mieć wpływ na to, jaka będzie przyszłość. Dzieje się więc metanoia w trzech wymiarach czasu: w przeszłości, którą pamiętamy i którą chcemy przekroczyć, teraźniejszości, w której doznajemy aktualizacji nowej możliwości bycia sobą i przyszłości, której oczekujemy, jako miejsca spełniania się tego bycia. W kulturze doraźności brakuje conajmniej tego trzeciego wymiaru a częściej tak-

12 G. STEIner, Gramatyki tworzenia, wyd. cyt. s. 12. 
że wymiaru przeszłości. Metanoi towarzyszyć więc tu musi swego rodzaju creatio ex nichilo polegające na zaktualizowaniu pełni czasu i uruchomieniu współkonstytuowania się przeszłości, przyszłości i teraźniejszości. Paradoksalnie z kultury doraźności, w której nie ma miejsca na twórczość można wydostać się jedynie dzięki twórczemu zaktualizowaniu pełni czasu.

Takie zaktualizowanie dokonuje się w kulturze ekologicznej. Ta kultura wyrasta z paradygmatu myślenia porządkowanego przez metaforę ekosystemu wypierającą nowożytną metaforę maszyny. Pojęcie ekosystemu samo będąc metaforą nawiązującą do wyobrażenia domu i systemu, jest punktem wyjścia do zrozumienia ugruntowanej na nim metafory innego typu, jakby wyższego rzędu, metafory już nie projektującej rozumienie określonego przedmiotu poznania, ale metafory porządkującej myślenie w paradygmacie ekologicznym. Z perspektywy przekonania Donalda Dawidsona, że metafory odróżnia od innych wyrażeń nie „znaczenie”, lecz „użycie”, ${ }^{13}$ zauważamy, że pojęcie ekosystemu staje się metaforą, gdy używane jest w specyficzny sposób. Podobnie jak stwierdzenia „głos z ciemności”, „czarna dziura” itp. „Użycie” wprowadza pozajęzykowy kontekst „promieniujący” znaczenia. „Eco” i „system” odniesione do układu biocenozy i biotopu / czyli zbioru wszystkich populacji wszystkich gatunków zasiedlających określony obszar i nieożywionych elementów terenu, na którym występuje biocenoza/ są określeniami metaforycznymi. „Ekosystem” przeniesiony z obszaru biologii, w obszar rozważań metafizycznych, staje się jakby rodzajem modelu, który pełni funkcję inspirującą i sugeruje możliwości interpretacyjne w odniesieniu do podejmowanych przez metafizyków zagadnień, a w konsekwencji zaczyna porządkować całe myślenie w paradygmacie nauki. Ekosystem to, holistycznie postrzegany, otwarty układ funkcjonalny, którego elementy współtworzą go i są współtworzone przez niego a w konsekwencji współtworzą siebie nawzajem. Układ ten zachowuje własności swoich elementów tzn. nie może istnieć w izolacji, jest elementem układu szerszego, który współtworzy i przez który jest współtworzony. Do jego zrozumienia przydatne okazuje się pojęcie „systemu względnie izolowanego" z oryginalnej koncepcji systemów zaproponowanej przez Romana Ingardena. Pojęcie systemu Ingarden wprowadził w kontekst refleksji o odpowiedzialności a pojęcie systemów względnie izolowanych było potrzebne przy omawianiu warunków, jakie spełniać musi podmiot odpowiedzialności. Warunkiem podstawowym bycia podmiotem odpowiedzialności jest posiadanie „w sobie centrum działania, które umożliwia /.../ uchwycenie inicjatywy"14 . Osoba będąca podmiotem odpowiedzialności musi też „mieć w swej budowie urządzenia obronne, aby nie przeszkadzano jej w działaniu"15. Jednocześnie musi być otwarta na otoczenie. Jak pi-

13 D. Dawidson, Inquiries into Truth and Interpretation, Oxford 1984, s. 259.

14 R. Ingarden, O odpowiedzialności i jej podstawach ontycznych, tłum. A. Węgrzecki, [w:] tenże: Książeczka o człowieku, WL, Kraków 1972, s 133.

$15 \mathrm{Jw}$. 
sze Ingarden, osoba odpowiedzialna „W swoich właściwościach i postępowaniu musi być tedy «otwarta» i podatna, a zarazem pod innym względem chroniona i niewrażliwa” ${ }^{16}$. Zdaniem Ingardena „działająca osoba (pewna całość stanowiąca jedność wraz z ciałem) musi tworzyć system względnie izolowany, i to system całkiem szczególnego rodzaju, który nie jest możliwy u rzeczy martwych, a który także nie u wszystkich istot żywych może się zrealizować"17. Pojęcie systemów względnie izolowanych pomaga myśleć o specyfice ekosystemu.

W odniesieniu do ekosystemu możemy zrezygnować z punktowości „teraz”. Teraźniejszość nie musi być sprowadzana do punktu przejścia między przeszłością a przyszłością, może oznaczać pewien zaktualizowany sposób bycia realizowany w ekosystemie. Teraźniejszość może trwać między przeszłością zakończoną momentem inicjacji tego bycia a przyszłością rozpoczynającą się momentem inicjacji nowego sposobu bycia. Teraźniejszość jest więc dynamicznym, żywym procesem aktualizacji potencjalności implikowanej przez system $\mathrm{w}$ jaki uporządkowało się to, co zaktualizowane z potencjalności bytu. W tym kontekście przeszłość jest teraźniejszością bycia, którego już nie ma a przyszłość teraźniejszością bycia, które dopiero będzie. Czas ma tu wymiar trwania i związany zostaje z twórczością. Twórczością jest inicjowanie jakiegoś nowego systemu bycia, nowej teraźniejszości. Aktualizacje kolejnych teraźniejszości dokonują się na tle niezmiennej wieczności, która ofiarowuje możliwość zaktualizowania kolejnego bycia bytu. Ta niezmienna wieczność stanowi odniesienie dla pomiarów długości kolejnych teraźniejszości i usytuowania ich początków i końców. Ją usiłują odmierzać kalendarze, klepsydry, zegary wodne, mechaniczne i elektroniczne. Okres drgań atomu cezu, który współczesna nauka przyjęła za najbardziej ścisłą miarę czasu i spalanie kadzideł na antycznym Oriencie to zestandaryzowane w danej epoce historyczno-technicznej - kody pomiaru idealnego czasu matematycznego ściśle związanego z wizją wiecznej niezmienności, równomiernego, punktowego czasu-liczby. Czas matematyczny to jakby rytm metronomu stanowiący tło dla czasu-trwania, który można porównać do czasów utworów muzycznych, w których długość i krótkość, szybkość i powolność, są zarazem spętane rytmem metronomu i od niego wyzwolone ${ }^{18}$.

16 Jw.

17 Jw., s. 134

18 George Steiner tak pisze o tej ambiwalencji: „Takie terminy jak ,allegro’ bądź ,adagio’ są niezbywalnie historyczne, techniczne i subiektywne. Ciasne następstwo muzycznych konfiguracji daje wrażenie vivace; tam gdzie sa mniej liczne czy bardziej rozciąnnięte, pojawia się odczucie powolności. Wszelako z każdym taktem kompozytor i wykonawca mogą odmienić zakładany efekt. Są miniatury Weberna niekiedy trwające mniej niż minutę „standardowego czasu”, które uchu wydają się powolne i przestronne. Są u Beethowena larga, których formalna powolność rodzi wrażenie niezwykłej gęstości w czasie. Słyszałem Richtera, który szybki jak błyskawica tryl Liszta zagrał w sposób sugerujący nieskończoność. Nie ma innej formy ludzkiego wyrazu, w której możliwość synchronni i niezgody pomiędzy czasem i trwaniem byłyby tak różnorodne i płodne jak w muzyce." /G. Steiner: Gramatyki tworzenia, wyd. cyt., s. 216. 
Bóg może tworzyć $\mathrm{z}$ bezczasowości - z aeternitas, i może tworzyć byty, które mają tylko swoją wieczną teraźniejszość - aevum. W tej teraźniejszości zawierają się wszystkie możliwości zaistnienia, cała kosmologiczna potencjalność otwarta. Człowiek tworząc musi zmieniać teraźniejszość w przeszłość i inicjować teraźniejszość przyszłości. Wszystkie ludzkie wytwory dzieją się w czasie, wszystkie mają początek i koniec. Wszystkie też w mniejszym lub większym stopniu mają swoją własną teraźniejszość, co najwyraźniej dostrzegamy w przypadku dzieł sztuki, które generują nie tylko swój własny świat, ale jednocześnie swoją własną przestrzeń temporalną, wewnętrzne trwanie. Mogą rozpędzać to trwanie aż do przeczucia bezkresu lub napełniać go taką intensywnością drgań, która uświadamia ambiwalencję między nieskończonością i nicością. Mogą też zatrzymywać czas w abstrakcjach, monumentalnych bryłach, więzić go w specyficznym zestawieniu dźwięków, zacierać granicę między ruchem a wiecznością w fotografii. Zupełnie inny czas proponują dzieła nauki. Ich czas ma charakter matematyczny, jest nieskończenie podzielny i niezmiennie wieczny, mierzony z coraz większą dokładnością stara się umożliwić koincydencję operacji i eksperymentów przeprowadzanych w różnych miejscach i momentach. Teraźniejszość dzieła naukowego jest na tyle przewidywalna i jednorodna, że eliminuje ona perspektywę przyszłości i w pewnym sensie zatrzymuje czas. Zarówno dzieła sztuki jak i dzieła nauki żyją nie tylko własną teraźniejszością, ale wpisują się też w trwanie świata i kolejnych teraźniejszości kultury. W ten sposób powstają opisywane w historii sztuki i historii nauki ich dzieje. Cenna jest umiejętność docierania poprzez kontekst, w którym stykamy się z dziełem do jego „teraźniejszości”, cenna, bo skutkuje wzbogaceniem „teraźniejszości” kontekstu. Może być ona tym bardziej wzbogacona przez elementy przeszłości, im intensywniejszą własną teraźniejszość one mają. Łatwo znaleźć takie wzbogacające naszą teraźniejszość elementy z przeszłości w obszarze sztuki, filozofii i nauki, trudniej w obszarze mających charakter służebny: technice, ideologii i polityce.

Elementy systemu bycia, nie tylko wzbogacają system, ale go współtworzą inspirując swoim byciem otoczenie do trwania będącego odpowiedzią na ich bycie. Twórcze zmiany w systemie możliwe są, gdy przynajmniej niektóre jego elementy mają własną teraźniejszość i mogą albo współbrzmieć albo pozostawać w opozycji do bycia systemu. Zmiana teraźniejszości systemu nie musi wtedy skutkować unicestwieniem jego elementów. Ponadto możliwa jest taka zmiana teraźniejszości elementu, która stanie się przyczyną zmiany teraźniejszości systemu.

Kultura doraźności atomizuje trwanie. W konsekwencji teraźniejszość nie ma tu ani przyszłości ani przeszłości. Kultura ekologiczna natomiast pozwala traktować teraźniejszość jak względnie izolowany system trwania, posiadający jak Ingardenowska osoba odpowiedzialna „w sobie centrum działania, które umożliwia /.../ uchwycenie inicjatywy"19 . Taka teraźniejszość jest spójną całością

19 R. Ingarden, O odpowiedzialności i jej podstawach ontycznych, tłum. A. Węgrzecki, [w:] tenże: Książeczka o człowieku, WL, Kraków 1972, s 133. 
narzucającą przebieg swojemu trwaniu i jednocześnie jest otwarta na otoczenie. Ta otwartość sprawia, że teraźniejszość, która wyłania się twórczo z przeszłości może w ten sam sposób owocować przyszłością. W paradygmacie myślenia ekologicznego życie i twórczość współbrzmią ze sobą a człowiek jest odpowiedzialny i za teraźniejszość, którą współkonstytuuje i za przyszłość, jaką może współtworzyć twórczo przekształcając teraźniejszość.

\title{
Civilization ecological instead of civilization immediate
}

\author{
SUMMARY
}

In the paper has been presentend two possible replies of human being to situation, whites imply contemporary world. One - civilization immediate - consist in adaptation of this situation, second - civilization ecological - consist in creative transcendence of this situation First - enter in modern paradigm of thinking, other - in paradigm of ecological thinking. 